\title{
Transport-induced Changes in Selected Biochemical Indices in Broilers as Affected by Ambient Temperatures
}

\author{
Petra Vošmerová ${ }^{1}$, Iveta Bedáňová1, Petr Chloupek ${ }^{1}$, Jan Chloupek ${ }^{2}$, \\ Pavel Suchý̉ ${ }^{3}$ Jr. Vladimír Večerek ${ }^{1}$
}

\begin{abstract}
${ }^{1}$ Department of Veterinary Public Health and Toxicology, Faculty of Veterinary Hygiene and Ecology, ${ }^{2}$ Department of Nutrition, Livestock Breeding and Animal Hygiene, Faculty of Veterinary Hygiene and Ecology, ${ }^{3}$ Department of Human Pharmacology and Toxicology, Faculty of Pharmacy, University of Veterinary and Pharmaceutical Sciences in Brno

Received October 7, 2009

Accepted May 13, 2010
\end{abstract}

\begin{abstract}
The effects of transportation to the slaughterhouse (catching, crating, loading, transport) at various ambient temperatures on selected biochemical indices were monitored in a group of unsexed ROSS 308 broiler chickens aged 42 days. The broilers were sampled at three different sampling times (prior to loading, after loading, and after $70 \mathrm{~km}$ transport) at three different ambient temperatures $\left(-5\right.$ to $+5{ }^{\circ} \mathrm{C}, 10$ to $20^{\circ} \mathrm{C}, 25$ to $\left.35^{\circ} \mathrm{C}\right)$. Corticosterone contents in broilers after loading and after transport were significantly higher $(P<0.01)$ than before loading. The highest corticosterone concentration was found in broilers that were handled (loaded and transported) at lower temperatures $\left(-5^{\circ} \mathrm{C}\right.$ to $\left.+5^{\circ} \mathrm{C}\right)$ and this value was significantly $(P<0.01)$ lower than in broilers handled under both other monitored temperature ranges. The results of this study prove that the stress-inducing procedure to which commercial broilers are exposed in connection with transport to the slaughterhouse induces strong changes in selected biochemical indices, and that these changes are highest in winter months at a lower ambient temperature.
\end{abstract}

Corticosterone, transportation, broiler chicken, stress, welfare

Commercial broiler chickens are exposed to a number of potential stress-inducing processes prior to slaughter, including transit to the slaughterhouse that involves many procedures, such as catching, crating, loading, self-transportation, lairage, etc. The handling, loading, transporting and unloading of animals can have extremely important effects on their welfare (Broom 2005). During transport to the processing plant, the birds may be exposed to physiological stress due to changes of environment, social disturbances, handling and restraint, and physical stress due to food deprivation, withdrawal of water, changes in microclimatic conditions, acceleration, vibration, motion, noise, fatigue, and sometimes pain (Nicol and Scott 1990; Mittchell et al. 1992; Mittchell and Kettlewell 1998; Terlouw et al. 2008). These stressors associated with transport to the slaughterhouse can cause fear and distress in birds, and in some cases high mortality (Mench 2004). Mortality as a measurement of transport stress and poor welfare during transportation in poultry has been investigated in many studies. Vecerek et al. (2006) studied mortality in broilers and Voslarova et al. (2007a) mortality in hens and roosters transported to processing plants to assess the effect of transport distance and the effect of the seasons of the year. Voslarova et al. (2007b) studied differences in mortality rates during transport of poultry species for slaughter.

The serious consequences of transport stress in poultry also include changes in behavior; changes in physiological variables, in particular hematological, enzymatic and hormonal changes; and pathological changes, in particular changes to the adrenal gland, bones and muscles (Gyimothy 2004). Corticosterone is the principal glucocorticoid released by the avian adrenal gland in response to various stress stimuli, and elevated plasma corticosterone is therefore a widely accepted indicator of stress condition in birds ( $\mathrm{CFF}$ arlane and Curtis 1989). The crating and transportation of commercial broilers cause increased production of

Address for correspondence:

MVDr. Petra Vošmerová

Department of Veterinary Public Health and Toxicology

Faculty of Veterinary Hygiene and Ecology

University of Veterinary and Pharmaceutical Sciences

Palackého 1/3, 61242 Brno, Czech Republic

Phone: +420 541562778

Fax : +420541562 790

E-mail: vosmerovap@vfu.cz

http://www.vfu.cz/acta-vet/actavet.htm 
adrenal hormones and lead to an elevated plasma corticosterone concentration in broilers (Kannan and Mench 1996; Kannan et al. 1997). Nijdam et al. (2005) who compared manual catching with a mechanical catching method in broilers before their transport to the slaughterhouse reported that corticosterone levels indicate the same amount of stress for both methods. The dynamics of the corticosterone, glucose and lactate contents were approximately the same in this experiment. Plasma concentrations of these biochemical indices increased at the start of the catching process, and increased still further during transport, shackling and stunning at the processing plant. According to Ondrašovičová et al. (2008), rough handling and long journeys have the greatest adverse effects on poultry welfare during transportation. In this study, the time in transit and the distance between the farm and the slaughterhouse contributed to a decrease in glucose concentrations in broilers and an increase in corticosterone concentrations in the blood of the birds. Pijarska et al. (2006) describe lower glucose plasma concentrations in chickens after transportation lasting $18 \mathrm{~h}$. Freeman et al. (1984) observed a consistent increase in plasma corticosterone levels resulting from two-hour and four-hour transportation of broilers, which was higher in winter than in summer. According to Yalcin et al. (2004), blood glucose was significantly higher in broilers transported during the summer than in broilers transported during the autumn, but was not changed by pre-slaughter treatment (catching, crating and transportation) in their experiment. Chloupek et al. (2008) describe a significant decrease in glucose and triglycerides concentrations in broilers after crating for $4 \mathrm{~h}$ and $8 \mathrm{~h}$.

The changes in the thermal microclimate to which birds are exposed in the transport vehicle were found to represent one of the major sources of transportation stress (Mitchell et al. 1992). Kataria et al. (2008) reported that serum corticosterone, glucose and triglycerides increased significantly and total proteins decreased in broiler chickens at high ambient temperatures $\left(42-45^{\circ} \mathrm{C}\right)$ and glucose and triglycerides levels were lower at low temperatures $\left(13-16^{\circ} \mathrm{C}\right)$. According to Lin et al. (2000), the plasma glucose was increased by heat exposure $\left(35^{\circ} \mathrm{C}\right)$ and this effect was aggravated by longer exposure.

The aim of our study was to specify the effect on the well-being of broilers of stress during the course of processes associated with $70 \mathrm{~km}$ transport at various ambient temperatures.

\section{Materials and Methods}

\section{Animals and treatment}

Committee on animal care in research approved the experimental design (No. 26/2006). The effects of transport with regard to ambient temperature on selected biochemical indices in meat poultry hybrids were monitored in a group of unsexed ROSS 308 broilers (total number 180) aged 42 days. From the first day after hatching, the broilers were housed on deep litter in a commercial barn with controlled light, heating, hygiene and feeding patterns according to standard breeding requirements for meat hybrid poultry. The ambient temperature in the barn was gradually decreased from $30 \pm 1{ }^{\circ} \mathrm{C}$ on $\mathrm{Day}$ 1 to $20 \pm 1{ }^{\circ} \mathrm{C}$ on the last day of fattening (Day 42). Relative humidity ranged between $20 \%$ and $60 \%$ depending on the ambient temperature. When the broilers were 42 days old, 30 chickens were selected at random for tests: 10 of them were sampled before any handling (group Prior to loading), 10 broilers were sampled after crating into transport crates (group After loading) and 10 broilers were sampled after $70 \mathrm{~km}$ transport (group After transport). These tests with 30 broilers were carried out in three various periods with different ambient temperatures (from $-5^{\circ} \mathrm{C}$ to $+5^{\circ} \mathrm{C}$, from $10{ }^{\circ} \mathrm{C}$ to $20^{\circ} \mathrm{C}$, from $25^{\circ} \mathrm{C}$ to $35^{\circ} \mathrm{C}$ ), which approximately correspond to temperature conditions during transport in individual seasons of the year (winter, spring or autumn, summer). The whole experiment was repeated twice, so that a total number of 180 samples were obtained. Blood samples were collected within $1 \mathrm{~min}$ of capture in order to ensure that the levels of the monitored indicators were not affected by stress induced by pre-sampling handling (Voslarova et al. 2008). The ratio of sexes of the broilers in the test was $50 \%$ to $50 \%$. The effect of sex was not, however, monitored during the test, as preliminary tests have shown it not to be significant. For biochemical examinations, the blood samples were stabilized with heparin (heparin concentration in blood samples $<1 \%$ ).

Biochemical examinations

The heparinized blood was centrifuged at $837 \mathrm{~g}$ for $10 \mathrm{~min}$, and plasma samples stored at $-80{ }^{\circ} \mathrm{C}$ in Eppendorf test tubes until the analyses were performed. Selected plasma biochemical indices: glucose, lactate, triglycerides (TG) and total protein (TP) were measured by a Cobas EMira biochemical analyzer using commercial test kits (Biovendor - Laboratorni medicina a.s., CZ). The plasma corticosterone concentration was measured using a commercial Corticosterone EIA Kit (Cayman Chemical, USA). 
Statistics

The results were analyzed using the statistical package Unistat 5.1. (Unistat Ltd., GB). The data were subjected to a two-way ANOVA with sampling time (prior to loading, after loading, after transport) and ambient temperature (from -5 to $+5{ }^{\circ} \mathrm{C}$, from 10 to $20{ }^{\circ} \mathrm{C}$, from 25 to $35^{\circ} \mathrm{C}$ ) as the main effects, along with their interactions. Square root (glucose, lactate) and logarithmic (corticosterone, TG, TP) transformations were used for analysis of variance, though actual mean values are presented. Significant differences among separate levels of effects in the experiment were evaluated using the Student-Newman-Keul multiple range test (Zar 1999).

\section{Results}

The results of biochemical examinations of broilers sampled prior to loading, after loading and after $70 \mathrm{~km}$ transport in three various periods with different ambient temperatures (from $-5{ }^{\circ} \mathrm{C}$ to $+5{ }^{\circ} \mathrm{C}$, from $10{ }^{\circ} \mathrm{C}$ to $20^{\circ} \mathrm{C}$, from $25^{\circ} \mathrm{C}$ to $35^{\circ} \mathrm{C}$ ) are presented in Table 1 .

Table 1. Selected biochemical indicators of broilers $(n=180)$ sampled prior to loading, after loading and after $70 \mathrm{~km}$ transport under three different ambient temperatures. Means \pm SEM and significance of multiple comparisons tests.

\begin{tabular}{|c|c|c|c|c|c|}
\hline \multirow[b]{2}{*}{ Effect } & \multicolumn{5}{|c|}{ Indicator } \\
\hline & $\begin{array}{c}\text { Cort } \\
(\mathrm{ng} / \mathrm{ml})\end{array}$ & $\begin{array}{c}\mathrm{TG} \\
(\mathrm{mmol} / \mathrm{l})\end{array}$ & $\begin{array}{c}\mathrm{TP} \\
(\mathrm{g} / \mathrm{l})\end{array}$ & $\begin{array}{l}\text { Glucose } \\
(\mathrm{mmol} / \mathrm{l})\end{array}$ & $\begin{array}{l}\text { Lactate } \\
(\mathrm{mmol} / \mathrm{l})\end{array}$ \\
\hline \multicolumn{6}{|l|}{ Sampling time } \\
\hline Prior to loading & $0.92^{\mathrm{c}} \pm 0.10$ & $0.59^{\mathrm{a}} \pm 0.02$ & $38.24^{\mathrm{b}} \pm 0.61$ & $14.12^{a} \pm 0.17$ & $5.40^{b} \pm 0.18$ \\
\hline After loading & $6.87^{\mathrm{a}} \pm 0.49$ & $0.61^{\mathrm{a}} \pm 0.03$ & $42.43^{\mathrm{a}} \pm 0.81$ & $13.99^{\mathrm{a}} \pm 0.22$ & $7.30^{\mathrm{a}} \pm 0.35$ \\
\hline After transport & $3.61^{b} \pm 0.28$ & $0.53^{b} \pm 0.02$ & $37.28^{\mathrm{b}} \pm 0.70$ & $14.08^{\mathrm{a}} \pm 0.17$ & $4.86^{\mathrm{b}} \pm 0.16$ \\
\hline \multicolumn{6}{|c|}{ Ambient temperature } \\
\hline$-5^{\circ} \mathrm{C}$ to $+5{ }^{\circ} \mathrm{C}$ & $5.56^{\mathrm{a}} \pm 0.58$ & $0.54^{\mathrm{b}} \pm 0.01$ & $38.54^{\mathrm{a}} \pm 0.50$ & $14.62^{a} \pm 0.13$ & $6.05^{\mathrm{a}} \pm 0.29$ \\
\hline $10^{\circ} \mathrm{C}$ to $20^{\circ} \mathrm{C}$ & $2.76^{b} \pm 0.28$ & $0.66^{\mathrm{a}} \pm 0.02$ & $39.62^{\mathrm{a}} \pm 0.80$ & $13.15^{b} \pm 0.16$ & $6.23^{\mathrm{a}} \pm 0.34$ \\
\hline $25^{\circ} \mathrm{C}$ to $35^{\circ} \mathrm{C}$ & $3.78^{\mathrm{b}} \pm 0.36$ & $0.54^{\mathrm{b}} \pm 0.03$ & $39.79^{a} \pm 0.94$ & $14.42^{a} \pm 0.20$ & $5.28^{a} \pm 0.18$ \\
\hline
\end{tabular}

Cort $=$ corticosterone, $\mathrm{TG}=$ triglycerides, $\mathrm{TP}=$ total protein

Means within the same effect and column lacking a common letter of superscript $(\mathrm{a}, \mathrm{b}, \mathrm{c})$ differ $(P<0.05)$

The results regarding the effect of sampling time show that the highest corticosterone concentration was found in broilers after loading, then significantly decreased in broilers after transport $(P<0.01)$, though this lowering did not reach the initial value of corticosterone in broilers prior to loading. The corticosterone content prior to loading was the lowest and significantly $(P<0.01)$ different from the corticosterone contents in the groups After loading and After transport. The concentration of TG in broilers after loading was not different from the TG content in broilers prior to loading. The plasma TG concentration in broilers significantly $(P<0.05)$ decreased after transport. Concentrations of TP and lactate showed similar changes throughout the monitored sampling times. Concentrations of these indices were significantly $(P<0.01)$ increased after loading in comparison to concentrations prior to loading, then decreased significantly $(P<0.01)$ in broilers after transport. Plasma concentrations of TP and lactate in broilers after transport were even lower than the initial concentrations prior to loading, although this difference was not significant. Glucose levels did not show any significant changes throughout the monitored sampling times.

The results regarding the effect of ambient temperature show that the highest corticosterone concentration was found in broilers that were handled (loaded and transported) under the lowest temperatures $\left(-5^{\circ} \mathrm{C}\right.$ to $\left.+5^{\circ} \mathrm{C}\right)$, and this value was significantly $(P<0.01)$ higher than in broilers handled under both other monitored temperature ranges. The plasma concentration of TG was significantly $(P<0.01)$ higher in broilers handled under mild temperatures $\left(10^{\circ} \mathrm{C}\right.$ to $\left.20^{\circ} \mathrm{C}\right)$ than in broilers handled under lower and higher temperatures. The glucose concentration was significantly $(P<0.01)$ lower in broilers handled under 
mild temperatures $\left(10^{\circ} \mathrm{C}\right.$ to $\left.20^{\circ} \mathrm{C}\right)$ than in broilers handled under both other monitored temperature ranges. Plasma TP and lactate concentrations did not show any significant changes throughout the monitored ambient temperatures in our experiment. The results of two-way ANOVA revealed that there was no significant interaction between sampling time and ambient temperature in our experiment.

\section{Discussion}

The results of this study prove that stress-inducing procedures to which commercial broilers are exposed in connection with transport to the slaughterhouse (including catching, crating, loading and self-transportation) induce strong changes in selected biochemical indices. As expected, these changes are specific in dependence on various ambient temperatures under which the broilers are handled and transported. Corticosterone concentrations show that the greatest stress effect on broilers is seen in handling and transport performed under the lowest ambient temperatures $\left(-5^{\circ} \mathrm{C}\right.$ to $\left.+5^{\circ} \mathrm{C}\right)$, when the highest corticosterone concentration in the broilers was found. This value is significantly higher than corticosterone levels in broilers transported under mild and even high temperatures. This is in agreement with Freeman et al. (1984), who found an increase in plasma corticosterone levels due to transportation of broilers, which was higher in the winter than in the summer. In contrast, Kataria et al. (2008) reported that serum corticosterone increased due to high ambient temperatures in broiler chickens, although the temperature range monitored in their experiment was considerably higher $\left(42-45^{\circ} \mathrm{C}\right)$ than in our study. As far as sampling time effects are concerned, it is evident from the results that the corticosterone content in broilers after transport is significantly lower than after loading. This may indicate that handling and crating represents a higher stress load than transport itself. Similarly, Nijdam et al. (2005) reported in their experiment monitoring stress effects of different catching methods that plasma corticosterone increased in broilers after the start of the catching process and during catching.

The concentration of glucose in the blood, which is one indicator of stress, was significantly higher in our study in broilers transported under extreme ambient temperatures, both higher and lower, when compared to the level of glucose in broilers transported under mild ambient temperatures. Similarly Yalcin et al. (2004) discovered that the content of glucose was significantly higher in broilers transported during the summer than in broilers transported during the autumn. Also Lin et al. (2000) describe that plasma glucose was increased by heat exposure $\left(35^{\circ} \mathrm{C}\right)$ and this effect was aggravated by longer exposure. Kataria et al. (2008) discovered that the concentration of glucose in the blood is lower at a temperature of $13-16^{\circ} \mathrm{C}$ than at higher temperatures. Our results also show that the glucose concentration was not affected by the sampling time in our experiment. This is in agreement with Yalcin et al. (2004) who reported that blood glucose was not changed by pre-slaughter treatments (catching, crating and transportation) in their experiment. In contrast, Nijdam et al. (2005) reported that plasma levels of glucose in broilers increased at the start of the catching process and further increased during transport in their experiment. Other authors describe a decrease in the glucose level after transport of broiler chickens (Ondrašovičová et al. 2008; Pijarska et al. 2006). According to our results, the lactate content was not affected by ambient temperatures in our study, although it was found to be highest in broilers after loading and subsequently decreased after transport. Similarly, Nijdam et al. (2005) found increasing plasma levels of lactate in broilers following the catching process but, in contrast to our experiment, these lactate levels increased still further during transport in their experiment. Our results show that the plasma TG concentration in broilers was not affected by loading, but decreased significantly after transport. In contrast, Chloupek et al. (2008) describe a significant decrease in triglyceride concentrations in broilers after 
crating, though the crating period monitored in their experiment was considerably longer (4 h, $8 \mathrm{~h}$ ) than in our study.

In conclusion, the stress-inducing procedures to which broilers are exposed during transport to the slaughterhouse have a negative effect on their welfare. This negative effect is further increased when transport and associated acts, such as catching, crating, loading and transport, are performed at lower $\left(-5^{\circ} \mathrm{C}\right.$ to $\left.+5^{\circ} \mathrm{C}\right)$ and higher $\left(25^{\circ} \mathrm{C}\right.$ to $\left.35^{\circ} \mathrm{C}\right)$ temperatures. It is necessary to emphasize considerate treatment of broilers, particularly during catching and crating, and to limit the negative effect of low and high ambient temperatures by means of the appropriate timing of transport and the use of means of transport that limit the negative effect of lower and higher temperatures.

\section{Vliv přepravy a teploty prostředí na vybrané biochemické ukazatele krevní plazmy u brojlerů}

Vliv přepravy na jatky (chytání, bednění, nakládání, vlastní přeprava) při různých teplotách prostředí na vybrané biochemické ukazatele byl sledován na skupině brojlerových kuřat ROSS 308 bez rozlišení pohlaví ve věku 42 dnů. Vzorky krve byly odebírány brojlerům ve třech různých časových obdobích (před naskladněním, po naskladnění, po $70 \mathrm{~km}$ přepravě) při třech různých teplotách prostředí (od -5 do $+5{ }^{\circ} \mathrm{C}$, od 10 do $20{ }^{\circ} \mathrm{C}$, od 25 do $\left.35^{\circ} \mathrm{C}\right)$. Hladina kortikosteronu po naskladnění a po přepravě byla významně $(P<0,01)$ vyšší než u brojlerů před naskladněním. Nejvyšší hladina kortikosteronu byla zjištěna $\mathrm{u}$ brojlerů, se kterými bylo manipulováno (naskladnění a přeprava) při nejnižší teplotě prostředí (od $-5^{\circ} \mathrm{C}$ do $\left.+5^{\circ} \mathrm{C}\right)$ a tato hodnota byla významně $(P<0,01)$ vyšší než u brojlerů, se kterými bylo manipulováno při dvou dalších sledovaných teplotách prostředí. Výsledky této studie ukazují, že stresové vlivy, kterým jsou brojleři vystaveni při přepravě na jatky, vyvolávají výrazné změny ve vybraných biochemických ukazatelích a tyto změny jsou největší v zimních měsících při nízkých teplotách okolí.

\section{Acknowledgements}

This study was supported by the Research Project No MSM6215712402 Veterinary Aspects of Food Safety and Quality.

\section{References}

Broom DM 2005: The effects of land transport on animal welfare. Rev sci tech Off int Epiz 24: 683-691

Chloupek P, Vecerek V, Voslarova E, Bedanova I, Suchy P, Pistekova V, Kozak A 2008: Effects of different crating periods on selected biochemical indices in broiler chickens. Berl Munch Tierarztl Wochenschr 121: 132-136

Freeman BM, Kettlewell PJ, Manning AC, Berry PS 1984: Stress of transportation for broilers. Vet Rec 114: 286-287

Gyimothy I 2004: Stress factors and stress responses in poultry breeding. Literature review. Magy Allatorv Lapja 126: $101-106$

Kannan G, Mench JA 1996: Influence of different handling methods and crating periods on plasma corticosterone concentrations in broilers. Br Poult Sci 37: 21-31

Kannan G, Heath JL, Wabeck CJ, Souza MCP, Howe JC, Mench JA 1997: Effects of crating and transport on stress and meat quality characteristics in broilers. Poult Sci 76: 523-529

Kataria N, Kataria AK, Gahlot AK 2008: Ambient temperature associated variations in serum hormones and interrelated analytes of broiler chickens in arid tract. Slov Vet Res 45: 127-133

Lin H, Du R, Gu XH, Li FC, Zhang ZY 2000: A study on the plasma biochemical indices of heat-stressed broilers. Asian Australas J Anim Sci 13: 1210-1218

McFarlane JM, Curtis SE 1989: Multiple concurrent stressors in chicks. 3. Effect on plasma corticosterone and the heterophil - lymphocyte ratio. Poult Sci 68: 522-527

Mench JA 2004: Management, handling, and transport of farm animals. Global Conference on Animal Welfare: An OIE Initiative, Proceedings, pp. 149-155

Mitchell MA, Kettlewell PJ, Maxwell MH 1992: Indicators of physiological stress in broiler chickens during road transportation. Anim Welf 1: 91-103

Mitchell MA, Kettlewell PJ 1998: Physiological stress and welfare of broiler chickens in transit: Solutions not problems! Poult Sci 77: 1803-1814 
Nicol CJ, Scott GB 1990: Pre-slaughter handling and transport of broiler-chickens. Appl Anim Behav Sci 28: $57-73$

Nijdam E, Delezie E, Lambooij E, Nabuurs MJA, Decuypere E, Stegeman JA 2005: Processing, products, and food safety - Comparison of bruises and mortality, stress parameters, and meat quality in manually and mechanically caught broilers. Poult Sci 84: 467-474

Ondrasovicova O, Saba L, Smirkjakova S, Vargova M, Ondrasovic M, Matta S, Lakticova K, Wnuk W 2008: Effects of vehicle-road transport on blood profile in broiler chickens. Medycyna Wet 64: 292-293

Pijarska I, Czech A, Malec H, Tymczyna L 2006: Effects of road transportation of chicks on blood biochemical indices and productive results of broilers. Medycyna Wet 62: 408-410

Terlouw EMC, Arnould C, Auperin B, Berri C, Le Bihan-Duval E, Deiss V, Lefevre F, Lensink BJ, Mounier L 2008: Pre-slaughter conditions, animal stress and welfare: current status and possible future research. Animal 2: 1501-1517

Unistat Ltd. 1998: Unistat statistical package for Windows, version 5.1. (London, GB).

Vecerek V, Grbalova S, Voslarova E, Janackova B, Malena M 2006: Effects of travel distance and the season of the year on death rates of broilers transported to poultry processing plants. Poult Sci 85: 1881-1884

Voslarova E, Janackova B, Vitula F, Kozak A, Vecerek V 2007a: Effects of transport distance and the season of the year on death rates among hens and roosters in transport to poultry processing plants in the Czech Republic in the period from 1997 to 2004. Vet Med-Czech 52: 262-266

Voslarova E, Janackova B, Rubesova L, Kozak A, Bedanova I, Steinhauser L, Vecerek V 2007b: Mortality rates in poultry species and categories during transport for slaughter. Acta Vet Brno 76: 101-108

Voslarova E, Chloupek P, Bedanova I, Suchy P, Pistekova V, Vecerek V 2008: The effect of pre-sampling handling time on blood plasma biochemical parameters of broilers. Dtsch Tierarztl Wochenschr 115: 62-65

Yalcin S, Ozkan S, Oktay G, Cabuk M, Erbayraktar Z, Bilgili SF 2004: Age-related effects of catching, crating, and transportation at different seasons on core body temperature and physiological blood parameters in broilers. J Appl Poult Res 13: 549-560

Zar JH 1999: Biostatistical analysis. 4th ed. Prentice Hall, Upper Saddle River, New Jersey, 663 p. 